\title{
An Experiential Approach to Teaching Inventory Cost Allocation Methods in Accounting
}

\author{
Yu-Ho Chi \\ University of Tennessee at Martin
}

In order to gain a better understanding of the Inventory Cost Allocation Methods, that represents the more commonly taught subject at university level around the world, the creative use of experiential learning exercises was employed. Undergraduate students commonly lack industry experience so role playing was used in teaching the topic to students at a North American University. Factors affecting students' grades were analyzed. Results indicate that experiential approach was the most significant factor contributing to learning and success as measured by grade scores. Exam scores were higher when students took part in the experiential approach and gained confidence in their learning. This research provides valuable insights for research scholars and institutional educators of undergraduate accounting students.

Keywords: experiential learning, inventory cost allocation methods

\section{INTRODUCTION}

This study investigates factors contributing to student performance and success in inventory cost allocation methods by focusing on the following factors: gender, age, standing (number of years in school), mathematics (math class taken), confidence, experiential (experiential learning versus traditional methods), and major. The analysis of confidence results shows that students find the experiential learning techniques to be highly useful to increase their confidence for learning course material. Experiential learning activity makes confidence an important factor in performing the task. These results also show that using experiential learning techniques in the subject of inventory cost allocation can enhance student performance relative to traditional teaching approaches. The success for students (higher exam score) in learning the material is higher when students have both the experiential approach and have confidence in their learning. Gender, age, standing, mathematics, and major have no effect on students' grades. Differences do exist between students who participate in the experiential learning and those who participate in the traditional lecture class.

Experiential learning is a term that refers to learning by doing, authentic, student centered, hands-on, and situated in relevant learning contexts (Kolb and Fry, 1975; Kolb and Kolb, 2005). Prior research indicates that experiential learning methods are superior since they enhance student performance and critical learning (Sheorey et al., 2020; Alkafaji and Gleason, 2019; Bethell and Morgan, 2011; Sternberg and Zhang, 2001; Montgomery et al., 1997; Breunig, 2005; King, 1993; Nnodim, 1997). Kern (2002) provides evidence of a positive effect on a hands-on model that can be used to help students learn inventory cost allocations. 
The purpose of this study is to extend Kern's (2002) research with application of Kolb's (1984) experiential learning model to examine the actual effectiveness of experiential learning relative to traditional teaching formats on the subject of inventory cost allocation methods by incorporating several new variables not considered by Kern (2002). The issues associated with inventory cost allocation have been of interest to many researchers both from a theoretical and practical viewpoint. Beginning with Sunder (1973) and continuing through Dopuch and Pincus (1988), empirical literature has examined the reactions of investors to a firm's switch from FIFO (First In, First Out) method to LIFO (Last In, First Out) method of valuing inventory. These studies provide evidence of the importance of inventory in judging a company's well-being.

However, there is little research into the efficacy of experiential pedagogy in cost allocation methods. Despite the fact that experiential learning has been shown to promote an-depth understanding of learning (Sheorey et al., 2020; Alkafaji and Gleason, 2019; Bethell and Morgan, 2011; Sternberg and Zhang, 2001; Montgomery et al., 1997), relatively few accounting educators have begun to integrate experiential learning strategies into their courses (Adler and Milne, 1997).

Many educators find that students have trouble assigning a dollar value to inventory using the different cost flow assumptions: LIFO, FIFO, and weighted average (Communicator, 1996). These difficulties and the resulting inappropriate journal entries result in a poor start regarding how to reflect inventory cost flows (Laux, 2007).

Moreover, Adler and Milne (1997) note that many traditional accounting curricula fail to promote students' interpersonal skills in addition to communication and problem solving skills. The lecture approach is criticized for its passive learning because students passively listen to and take notes without actively being engaged in lecture material (Dabbour, 1997). The absence of real participation makes it difficult for students to understand the basic concepts and procedures and may lead students to be confused (Communicator, 1996; Agrawal and Siegel, 1991).

Therefore, this study documents the use of an experiential learning approach to teaching inventory cost allocation methods. The primary goal of incorporating experiential learning techniques into an inventory cost allocation method is to provide students with an understanding of commonly used accounting methods and the proper application of inventory cost. Stated differently, it helps students understand the basics of cost flow assumptions by applying these concepts to a real-world setting. A view of how an experiential learning approach affects discipline-specific learning will be described later in this paper. The experiential approach is also consistent with educational research showing that students tend to comprehend complex concepts much better, and retain them as part of their body of knowledge much longer, when they become personally involved in the learning process (Light, 1990).

Kolb (1984) develops an approach to experiential learning theory that views experience as the source of learning and development, and provides a link between affective and cognitive domains. Kolb describes this learning process as a four-stage cycle which comprises different categories of learning abilities: concrete experience (feeling), reflective observation (thinking), abstract conceptualization (representation), and active experimentation (doing) (Charkins et al., 1985; Baker et al., 1986; Agrawal and Siegel, 1991). Stice (1987) shows that the students' retention of knowledge increases from $20 \%$ when only abstract conceptualization is involved to $90 \%$ when students are engaged in the four stages of learning.

This study contributes to this significant area of research by empirically examining the relationship between experiential learning strategies and student performance on the subject matter of inventory cost allocation methods in US. This research provides valuable insights for research scholars and institutional educators of undergraduate accounting students.

\section{PRIOR LITERATURE AND HYPOTHESIS DEVELOPMENT}

\section{Experiential Learning}

Experiential learning is identified as learning in which the student is in direct contact with concepts being studied (Keeton and Tate, 1978). Others have also proposed that students learn when they are actively involved with concrete experiences (Gaidis and Andrews, 1990; Walters and Marks, 1981). Experiential 
learning involves observing a concept or phenomenon and actually doing something with it (Kolb, 1984). The use of experiential learning techniques often occurs through class-based (role-playing, simulation) and field-based (practicum, internships) education (Lewis and Williams, 1994). One of the benefits of experiential learning is the immersion of the participant in the social constructions and cultural expectations specific to the experience (Lave and Wegner, 1991). Experiential learning involves participation and critical reflection on that participation (Kolb, 1984; Schon, 1983).

\section{Experiential Learning and Confidence}

Lightweis (2014) show that experiential learning helps students improve their soft skills. Students are able to connect the concepts learned with the situations found in the accounting profession, and the simulation builds confidence and motivates the students to learn more about enhancing the skills necessary for the accounting profession.

Cornell et al. (2013) investigate 117 students by administering a structured interview to individuals in charge of financial operations in a religious organization. The results show that the structured-interview experiential learning assignment successfully enhances student confidence and reduces anxiety. Students indicate that with the help of the tasks assigned during experiential learning, their self-confidence levels improve.

\section{Experiential Learning and Performance}

It is expected that there will be numerous benefits, including enhanced performance, and retention when experiential activities are employed in the classroom.

Kolb (1984) notes that the experiential learning model energizes the students as well as improves the depth on their understanding. Sheorey et al. (2020) reveal that service based experiential learning enhances students' understanding of social issues and creative thinking. Perry et al. (1996) demonstrate that experiential learning increases student performance while Mccarthy and Anderson (2000) show that students participate more in class and perform better on examinations.

Light (1990) shows that students comprehend complex concepts better, and increase retention when they are involved in the learning process. Stice (1987) reports that retention improves dramatically, from $20 \%$ to $90 \%$, when the Kolb's four stages of learning are employed as shown in Table 1. Cornell et al. (2013) find that experiential learning leads to changes in students' thoughts about themselves. Students better recall the classroom material, better understand the implementations of what they learn, and increase their interest in the topic.

Alkafaji and Gleason (2019) simulate a role-playing exercise and indicate that the students gain a better understanding of the actual audit process. DeNeve and Heppner (1997) use role-play simulations and find that student responses are highly positive both short-term and long-term. Experiential learning is intended to deepen the content of instruction by integrating theory and practice, to increase student motivation through the experience of applying knowledge, and to encourage students to develop their skills as independent scholars (Davis, 1993).

Studies also indicate that experiential learning improves students' enjoyment, enthusiasm, and maximize participation. Lawson (1995) provides evidence that students in classes employing experiential learning report a higher level of enjoyment. Student comments indicate that experiential learning assignments are the most enjoyable aspect of classes (O'Hara and Shaffer, 1995). Dabbour (1997), Kendrick (1996), and Stice (1987) find that experiential activities increase instructors' and students' enthusiasm for the learning process. 
TABLE 1

KOLB (1984) FOUR-STAGE LEARNING CYCLE

\begin{tabular}{|c|c|c|}
\hline $\begin{array}{l}\text { Kolb (1984) four-stage } \\
\text { learning cycle }\end{array}$ & & Practice of inventory cost flow methods \\
\hline Concrete experience & (feeling) & $\begin{array}{l}\text { Role-play } \\
\text { (Tompkins, 1998; Kern, 2002) }\end{array}$ \\
\hline Reflective observation & (thinking) & $\begin{array}{l}\text { Interaction between students } \\
\text { (Siegel et al.,1997; Millenbah and Millspaugh, 2003; } \\
\text { Shakarian, 1995; Kern, 2002) }\end{array}$ \\
\hline Abstract conceptualization & (representation) & $\begin{array}{l}\text { Concluding remarks } \\
(\text { Kern, 2002) }\end{array}$ \\
\hline Active experimentation & (acquisition) & $\begin{array}{l}\text { Taking examination } \\
\text { (Kern, 2002) }\end{array}$ \\
\hline
\end{tabular}

\section{Hands-on and Inventory Cost Allocation}

Kern (2002) demonstrates the use of a hands-on model based on a Fisher Price Rock-n-Stack ${ }^{\mathrm{TM}}$ toy to highlight the concepts involved with inventory cost allocations in an accounting environment. The toy is a spindle where rings of different colors and sizes may be stacked. Numbers representing unit costs are assigned to each colored ring. The entire stack of rings represents the cost of goods available for sale and Kern asks students whether this approach enhances their understanding of inventory cost allocations. The results indicate that a hands-on model assists students' understanding of the issues involved with allocating cost of goods available for sale between cost of goods sold and ending inventory. Students are better able to develop allocation schemes that reflect physical flow, income tax motivations, property tax motivations, income maximization, and ease of calculation. Without the model the groups experience a high degree of frustration and struggle with the allocations.

\section{Hypothesis Development}

Students taught using experiential learning have higher confidence in themselves and in their professional abilities (Rocha, 2000). Gray and Gibbons (2002) find that experiential learning increases confidence and improves preparation for the real world. Similarly, Arthur and Achenbach (2002) and BenAri (1998) note that experiential learning increases students' confidence and preparedness, motivation to learn, and both cultural sensitivity and understanding.

DeNeve and Heppner (1997) examine role-play simulations in an industrial psychology course. The results indicate that student responses are highly positive - both immediately following the simulation and in follow-up interviews conducted eight months later. Miller and Grocchia (1997) find that using a cooperative teaching format in a biology course increases satisfaction compared to a traditional format. It can be concluded that increasing student involvement can lead to enhanced student learning confidence. Extending this reasoning leads to the first research hypothesis.

H1: On examinations, students who have confidence in their having learned the material outperform students who do not have confidence in having learned the material.

Kern (2002) assesses the efficacy between the group that uses a hands-on problem-solving model and the group without a model in inventory cost allocations to see whether the students have developed an informed understanding of the concepts as a result of the experience. The result observes that the experimental group has significantly higher performance scores compared to the group without a model in inventory cost allocations. This finding is consistent with students' experience, not only allowing them to reach a new understanding of material but also asserting the fundamental relationship between an individual's reflective inquiry process and their ability to develop their own judgments (Dewar and Walker, 
1999). It is also consistent with the assertion that active learning is the path to understanding, rather than simply to memory (Caine and Caine, 1994).

It is important that students understand not only how to do accounting but also why. Ramsden (1992) finds that students' control over learning and the accommodation of individual differences in preferred ways of reaching understanding is enhanced by hands-on problem-solving methods. Montgomery et al. (1997) apply Kolb's (1984) experiential learning model to a school board simulation in an introductory education course and conclude that students are energized and they are personalizing an in-depth understanding of educational issues by using a simulation. Furthermore, studies of experiential learning illustrate that students have the greatest retention and develop mastery of material and skills more readily (Hamer, 2000). This leads to the following hypothesis.

H2: On examinations, students exposed to the experiential learning activities outperform those taught by traditional methods.

In addition, given the expectation that experiential learning affords students the opportunity to increase their confidence and have significantly higher performance scores, students' success (higher exam scores) in learning the material is higher when students have both the experiential approach and have confidence in their learning. This leads to the following hypothesis.

H3: The success for students (higher exam score) in learning the material is higher when students have both the experiential approach and have confidence in their learning.

\section{METHODOLOGY}

\section{Sample Selection}

This experiment was conducted across two "Principles of Accounting" classes at a medium-sized US public university - one formed the experimental group, the other, the control group. The experimental group $(\mathrm{N}=33)$ performed the experimental learning activity during the class period. The control group $(\mathrm{N}=31)$ received the same basic information in the form of a conventional lecture. The same professor instructed both classes, so there was no possible confounding effects of two different instructors. The students were told that they would be answering questions based on their classroom experiences. Both groups had the same assessment instrument. Immediately following this activity, student learning was assessed using an assessment instrument, shown in Appendix A3, with several objective questions.

\section{Application of Kolb's Model to Inventory Cost Allocation Method}

The experiment was conducted during a 75-minute class period. First, for the experiential learning group, ten minutes of the class were used for classroom management in the role-play setting in Stage 1. Concrete experience is how an individual gets involved in a new experience either through knowledge by acquaintance or direct practical experience (Kolb, 1984). Role playing provides students the opportunity to learn by doing (Alkafaji and Gleason, 2019) and is the most evolving technique in experiential learning (Manorom and Pollock, 2006). For the role-play in experimental learning activity in Stage 1, students were divided into groups of eight. Following the Kern (2002) study, students were placed as the accountants to count and value inventory in the Fisher Price Rock-n-Stack ${ }^{\mathrm{TM}}$ toy example.

Second, thirty minutes were used for student interaction with each other to discuss and identify the results in Stage 2. Students were given a worksheet shown in Appendix A2 that indicated the company's beginning inventory and purchases for the period, along with a unit cost.

Students subtracted the amount of ending inventory from the total cost of goods available for sale to determine the number of units sold. Using this information, students were required to complete the worksheet. This included finding the value of inventory, cost of goods sold, gross margin using LIFO, FIFO, and weighted average cost. They also prepared the journal entries for the selling company assuming the use of a perpetual inventory system. Students in the experimental class had more class participation 
than the students in the lecture-oriented setting. This allowed for students in the experimental class to be more actively involved in the learning process. Students also received feedback both within their groups and between groups. This peer feedback allowed the students to reflect upon their thoughts about inventory cost allocations

Reflective observation involves either watching others or developing observations about one's own experience (Kolb, 1984). Siegel et al. (1997) and Millenbah and Millspaugh (2003) indicate that interaction between the students at both the group and the individual student levels involves reflective observation. Shakarian (1995) claims that while experiential techniques are performed by small groups, working in groups pushes students to be critical and creative when identifying and reacting to problems. Group learning situations facilitate dialogues about problem-solving strategies and are an effective way to develop metacognitive skills (Bruer, 1993).

Third, ten minutes were used for the students' conclusion remarks in Stage 3. Abstract conceptualization implies creating theories to explain observations (Kolb, 1984). In this stage, students made assertions by providing evidence and documenting a summary of cost allocations and rationales for these allocations in Table 2. For the experimental class, the interaction enabled students to develop alternative allocation schemes. Illustrating higher order thinking, the experimental students provided justifications for alternative inventory costing. The alternative justifications included capturing the actual physical flow of the inventory, choice of method to reduce income taxation, boosting reported earnings through reducing cost of goods sold, enhancing assets on the balance sheet, and the ease of calculating either cost of goods sold or ending inventory.

In abstract conceptualization of Stage 3, Kern (2002) documents that students are able to clearly identify definitions and financial statement components, understand how the use of different methods impacts the income statement and balance sheet, and portray the impact of method choice on financial reporting and tax reporting.

TABLE 2

STUDENT-GENERATED COST ALLOCATIONS AND POSSIBLE RATIONALE

\begin{tabular}{|l|l|}
\hline Cost flow assumption & Rationale \\
\hline Weighted average & Simple to calculate \\
\hline FIFO & Consistent with physical flow \\
& Ending inventory cost represents most recent purchases \\
& Better represents value of inventory on balance sheet \\
& Usually results in a higher income \\
\hline LIFO & $\begin{array}{l}\text { May be consistent with actual physical flow } \\
\text { Reduces net income and income taxes } \\
\end{array}$ \\
& Provides a conservative measure of earnings and ending inventory \\
\hline
\end{tabular}

Note: students conclude remarks by providing evidence and documenting a summary of cost allocations and rationales for these allocations (Stage 3).

Fourth, twenty-five minutes were used for completing the assessment instrument in Stage 4. Active Experimentation deals with the process of testing existing ideas by creating new experiences (Kolb, 1984). In active experimentation of stage 4 , students took the examination including questions on their perspective on learning.

For the control group, ten minutes of the class were used for classroom management, forty minutes for a traditional lecture-oriented approach in which inventory cost allocations were discussed using a numerical example shown in Appendix A2, and twenty-five minutes for completing the assessment instrument shown in Appendix A3 for the assessment instrument. The calculations involved allocating cost of goods sold and ending inventory. In addition, several concepts such as the tax implications of these allocations were included in the lecture format. 


\section{Descriptive Statistic}

Table 3 presents descriptive statistics for the sample across several characteristics across two groups.

TABLE 3

DESCRIPTIVE STATISTICS FOR SAMPLE CHARACTERISTICS

Panel A: Group with Traditional Methods

\begin{tabular}{|l|c|c|c|c|c|}
\hline Variables & $\mathrm{N}$ & Mean & $\begin{array}{c}\text { Standard } \\
\text { Deviation }\end{array}$ & Minimum & Maximum \\
\hline GRADE & 31 & 31.2903 & 16.0710 & 10.0000 & 60.0000 \\
\hline GENDER & 31 & 0.5161 & 0.5080 & 0.0000 & 1.0000 \\
\hline AGE & 31 & 19.4516 & 0.5679 & 19.0000 & 21.0000 \\
\hline STANDING & 31 & 2.1290 & 0.3407 & 2.0000 & 3.0000 \\
\hline MATHEMATICS & 31 & 1.9355 & 0.2497 & 1.0000 & 2.0000 \\
\hline CONFIDENCE & 31 & 1.5484 & 0.7228 & 1.0000 & 3.0000 \\
\hline MAJOR & 31 & 1.1613 & 0.5226 & 1.0000 & 3.0000 \\
\hline
\end{tabular}

Panel B: Group with Experiential Learning

\begin{tabular}{|l|c|c|c|c|c|}
\hline Variables & $\mathrm{N}$ & Mean & $\begin{array}{c}\text { Standard } \\
\text { Deviation }\end{array}$ & Minimum & Maximum \\
\hline GRADE & 33 & 83.6364 & 13.1857 & 30.0000 & 100.0000 \\
\hline GENDER & 33 & 0.4545 & 0.5056 & 0.0000 & 1.0000 \\
\hline AGE & 33 & 19.3333 & 0.4787 & 19.0000 & 20.0000 \\
\hline STANDING & 33 & 2.1515 & 0.3407 & 2.0000 & 3.0000 \\
\hline MATHEMATICS & 33 & 1.9394 & 0.2423 & 1.0000 & 2.0000 \\
\hline CONFIDENCE & 33 & 4.4848 & 0.9394 & 1.0000 & 5.0000 \\
\hline MAJOR & 33 & 1.1818 & 0.6351 & 1.0000 & 4.0000 \\
\hline
\end{tabular}

\section{Dependent Variable - Grade}

Similar to Kern (2002), the assessment questions were selected that were compatible with the learning objectives common to both the treatment group and the control group. Questions were based on short answer or complete the sentence. They were selected from the test bank included with textbook Horngren's 2018. The provided means are based on a 100 point examination.

The data from this assessment instrument are the primary means of testing hypotheses $\mathrm{H} 1, \mathrm{H} 2$, and $\mathrm{H} 3$. Questions 11 is the mean of testing hypotheses $\mathrm{H} 1$ where students were asked to rate the extent to which they found the traditional lecture/experiential learning techniques to be useful to build their confidence in having mastered the material.

\section{Statistical Analysis}

A regression model is estimated with students' grades as the dependent variable and confidence and experiential as the independent variables. The model is as follows. ${ }^{1}$ All variables are defined in the Appendix A1.

$$
\begin{aligned}
\text { GRADE } & =\gamma_{0}+\gamma_{1} \text { GENDER }+\gamma_{2} \text { AGE }+\gamma_{3} \text { STANDING }+\gamma_{4} \text { MATHEMATICS } \\
& +\gamma_{5} \text { CONFIDENCE }+\gamma_{6} \text { EXPERIENTIAL }+\gamma_{7} \text { MAJOR } \\
& +\gamma_{8} \text { CONFIDENCE } * \text { EXPERIENTIAL }+\varepsilon .
\end{aligned}
$$

The effect of gender (GENDER) is the most frequently studied factor in the education literature (Mavruk, 2019; Lumsden and Scott, 1987; Kern, 2002; Borg and Stranahan, 2002; Ballard and Johnson, 2005; Doran et al., 1991; Carpenter et al., 1993). Mavruk (2019) suggests that men outperform women in 
finance classes, whereas Carpenter et al. (1993) reveal that there are no significant differences between females and males in their academic performance in introductory accounting courses. Doran et al. (1991) demonstrate that male students perform better than females in Accounting Principles I, but not in Accounting Principles II. Lumsden and Scott (1987) report that female students do better on an economic essay exanimation. Borg and Stranahan (2002) conclude that gender does matter in a student's performance in Principles of Macroeconomics. Ballard and Johnson (2005) examine the differences between relationship of males and females ability to cope with accounting subjects. They conclude that women are likely to perform lower than men, and the gender variable is shown to have a significant relationship to the academic performance.

The empirical effects of age (AGE) on performance in accounting classes remain mixed. Duff (2004) indicates that age is not significantly associated to student academic performance nor progression of firstyear accounting and business economics undergraduates. Dunn et al. (2016) provide evidence on the relation between course scheduling and student performance in a Principles of Accounting (I) course, and indicates that mature students outperform younger students. However, Koh and Koh (1999) document that younger students perform better than older students in the accountancy degree program.

Mathematics skills (MATHEMATICS) is another variable of interest when predicting student success in accounting classes. Gist et al. (1996) report a positive effect of mathematics skills on performance of accounting students. Mathematics course score is an accepted variable in accounting course performance models in order to take the numeracy level of students into account. Fedoryshyn et al. (2010) fully focus on numeracy, and they report a significant correlation between mathematics skills and performance in accounting courses.

\section{RESULTS}

\section{Univariate Analyses}

Hypothesis H1 posits that students who have confidence in their learning the material outperform on the exam students who do not have confidence in learning the material. Hypothesis $\mathrm{H} 2$ states that the groups exposed to the experiential learning activities outperform those taught by traditional methods. Table 4 provides preliminary analyses related to this assertion. Observations are sorted by teaching approach type (traditional methods versus experiential learning) with the mean of all variables calculated. The mean GRADE is 31.2903 for traditional methods and 83.6364 for experiential learning. The difference is negative and highly significant at the one percent level in $\mathrm{t}$-tests $(\mathrm{t}=-14.28)$. It suggests that using experiential learning techniques in the classroom can enhance student performance on inventory cost allocation methods relative to traditional teaching approaches.

Similarly, the mean CONFIDENCE is 1.5484 for traditional methods and 4.4848 for experiential learning. The difference is negative and highly significant at the one percent level in $\mathrm{t}$-tests $(\mathrm{t}=-13.95)$. This evidence is consistent with the hypothesis, suggesting that the experiential learning activities help students understand inventory cost allocations better than traditional methods. The experiential learning activities increase student confidence in understanding material.

The other factors, GENDER, AGE, STANDING, MATHEMATICS, and MAJOR do not impact student performance. 
TABLE 4

DESCRIPTIVE STATISTICS AND T-TEST FOR TRADITIONAL LECTURE AND EXPERIENTIAL LEARNING GROUP

\begin{tabular}{|l|c|c|c|c|}
\hline Variable & $\begin{array}{c}\text { Traditional } \\
\mathrm{N}=31\end{array}$ & $\begin{array}{c}\text { Experiential } \\
\mathrm{N}=33\end{array}$ & $\begin{array}{c}\text { t Value } \\
(1)-(2)\end{array}$ & $\operatorname{Pr}>|\mathrm{t}|$ \\
\hline & Mean $(1)$ & Mean $(2)$ & & $-14.28^{* * *}$ \\
\hline GRADE & 31.2903 & 83.6364 & 0.49 & $<.0001$ \\
\hline GENDER & 0.5161 & 0.4545 & 0.90 & 0.6288 \\
\hline AGE & 19.4516 & 19.3333 & -0.25 & 0.3701 \\
\hline STANDING & 2.1290 & 2.1515 & -0.06 & 0.7999 \\
\hline MATHEMATICS & 1.9355 & 1.9394 & $-13.95^{* * *}$ & $<.0001$ \\
\hline CONFIDENCE & 1.5484 & 4.4848 & -0.14 & 0.8886 \\
\hline MAJOR & 1.1613 & 1.1818 & & \\
\hline
\end{tabular}

*** Indicates significance at 1 percent level; $* *$ indicates significance at 5 percent level; $*$ indicates significance at 10 percent level in a one-tailed test.

Table 5 provides the Pearson product moment correlations between the variables for the sample of grades. Consistent with the univariate analyses previously discussed, significant correlations between grade and confidence are observed in the hypothesized direction. The correlation analysis confirms that higher CONFIDENCE is associated with higher GRADE.

A statistically significant correlation in the hypothesized direction is also observed between grade (GRADE) and teaching approach (EXPERIENTIAL). In addition, there is a positive relationship between confidence and teaching approach. 


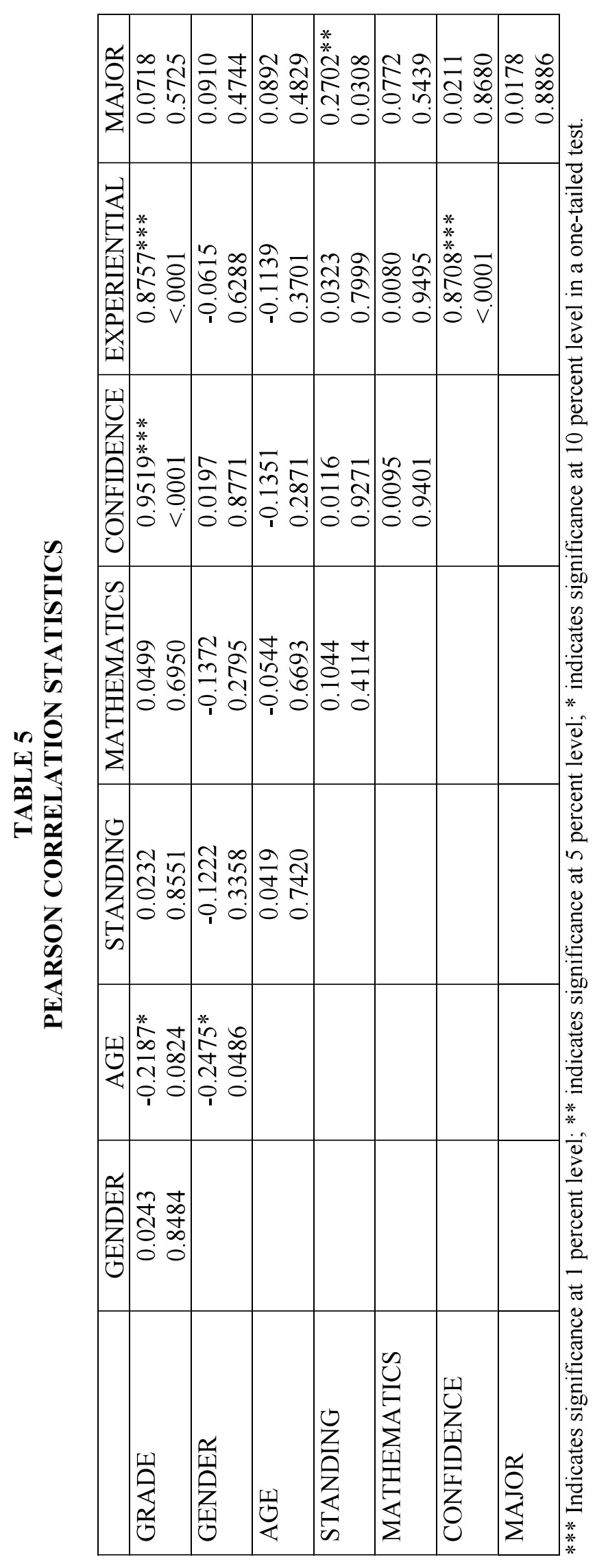

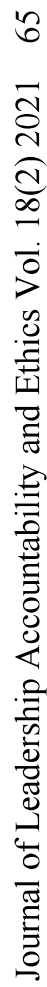




\section{Multivariate Analyses}

Since univariate tests are prone to the influence of other correlated variables that can affect students' grades, multivariate analyses are performed to include other controls in the analysis. Table 6 presents the results of the regressions of grades on confidence, experiential learning, and interaction between these two variables. The regression is used to test hypotheses $\mathrm{H} 1, \mathrm{H} 2$, and $\mathrm{H} 3$ while controlling for other variables that have been found to influence students' grades.

In the model, the coefficient on CONFIDENCE is positive and highly significant at the $p<0.01$ level, suggesting that students believe that experiential learning leads to more success in preparing inventory cost allocation methods than traditional methods. The experiential learning activities help students build confidence that they understand the material better than traditional methods. The evidence is consistent with $\mathrm{H} 1$ that students who have confidence in their having learned the material outperform students who do not have confidence in having learned the material.

The students indicate effectiveness of the experiential learning activity in conveying the subject matter and the ease with which it can be done. They express confidence in the use of experiential learning techniques as well as a belief that this technique helps in their preparation for the exams. They believe that they learn the concepts and are confident in applying them on assignments and exams. The results suggest that increase in confidence does impact students' performance, and confidence explains the crucial difference in performance. The experiential learning activity makes confidence an important factor in performing on the task. As students who are exposed to experiential learning techniques are more confident in performing in the subject, instructors should consider employing learning strategies that build confidence

The coefficient on EXPERIENTIAL is positive and highly significant at the $p<0.01$ level, suggesting that students who engage in the experiential learning activity perform significantly better than those exposed to the traditional methods. The results agree with $\mathrm{H} 2$, suggesting that using experiential learning techniques in the subject of inventory cost allocation can enhance student performance relative to traditional teaching approaches. Using experiential learning techniques may well enable students to absorb and retain information just as well as, if not better than, the more traditional methods.

The coefficient on the interaction term CONFIDENCE * EXPERIENTIAL is positive and highly significant at the $\mathrm{p}<0.01$ level, suggesting that the success for students (higher exam score) in learning the material is higher when students have both the experiential approach and have confidence in their learning. The result has been suggested that experiential learning techniques create a positive learning environment that not only allows students to actively participate with the material and each other, but also stimulates confidence to learn material that may not be achievable with other teaching methods.

No evidence is observed that the grades statistically associated with GENDER, AGE, STANDING, MATHEMATICS, and MAJOR.

TABLE 6

\section{REGRESSION RESULT}

$$
\begin{aligned}
\text { Model }: \text { Test }= & \gamma_{0}+\gamma_{1} \text { GENDER }+\gamma_{2} \text { AGE }+\gamma_{3} \text { STANDING }+\gamma_{4} \text { MATHEMATICS } \\
& +\gamma_{5} \text { CONFIDENCE }+\gamma_{6} \text { EXPERIENTIAL }+\gamma_{7} \text { MAJOR } \\
& +\gamma_{8} \text { CONFIDENCE } * \text { EXPERIENTIAL }+\varepsilon .
\end{aligned}
$$

\begin{tabular}{|l|c|c|c|}
\hline Variables & Coefficient & $\mathrm{t}$ Value & $\operatorname{Pr}>|\mathrm{t}|$ \\
\hline Intercept & 81.33583 & 1.91 & 0.0610 \\
\hline GENDER & -0.98668 & -0.45 & 0.6514 \\
\hline AGE & -5.81227 & -2.85 & 0.0061 \\
\hline STANDING & -1.61978 & -0.53 & 0.5972 \\
\hline MATHEMATICS & 1.57881 & 0.37 & 0.7143 \\
\hline CONFIDENCE & 26.35678 & $5.94^{* * *}$ & $<.0001$ \\
\hline EXPERIENTIAL & 31.52068 & $4.02^{* * *}$ & 0.0002 \\
\hline
\end{tabular}




\begin{tabular}{|l|c|c|c|}
\hline MAJOR & 3.05630 & 1.66 & 0.1033 \\
\hline CONFIDENCE * EXPERIENTIAL & 7.72789 & $-2.99^{* * *}$ & 0.0042 \\
\hline $\mathrm{N}$ & 64 & & \\
\hline Adj. $\mathrm{R}^{2}$ & 0.80 & & \\
\hline
\end{tabular}

*** Indicates significance at 1 percent level; ** indicates significance at 5 percent level; $*$ indicates significance at 10 percent level in a one-tailed test.

\section{CONCLUSION}

Despite the potential benefits of experiential learning methods, relatively few accounting faculties have universally chosen to integrate them into their courses. Concrete experience is often missing for most students for inventory cost allocation methods. Most students have never dealt with questions and issues involving concepts such as inventory, cost flow assumptions, or terminology such as cost of goods sold or ending inventory. As experiential learning has the potential to promote deep and lasting connections with course material, this approach can be successfully utilized when it is incorporated into students' learning, and improve students' understanding of inventory cost flow methods in accounting.

The results provide insights into the effectiveness of experiential learning techniques in the subject of inventory cost allocation. These techniques play a crucial determinant of student performance. Exam scores are higher when students have both the experiential approach and have confidence in their learning. This evidence supports the assertion that enhanced learning and confidence comes from students' using roleplaying within an experiential learning environment.

It is expected that the confidence and the use of experiential learning activities will better engage the students, and they will reflect more critically on the activity; obtain more useful insight and learning; improve retention; and perform better than students in the traditional lecture course. Instructors should consider employing an experiential approach and strive to build student confidence that they understand the material. This will lead to a higher performance on the examination and, potentially, lead to their retention of the material.

The primary limitations of the study are that the experiment is only conducted in one university setting. More implementation of experiential learning techniques in different universities may address the research problem more effectively in future studies.

\section{ENDNOTE}

1. In order to control for the presence of heteroscedasticity, I apply White's (1980) heteroscedasticity constant standard errors for all regression analyses in this study.

\section{REFERENCES}

Adler, R.W., \& Milne, M.J. (1997). Improving the Quality of Accounting Students' Learning Through Action-oriented Learning Tasks. Accounting Education: In International Journal, 6(3), 191-215.

Agrawal, S.P., \& Siegel, P.H. (1991). Introduction to Accounting: An Experiment in Experiential Learning Theory. Southwest Business Review, 1, 99-118.

Alkafaji, Y., \& Gleason, K.C. (2019). The Use of Role-Playing in the Auditing Classroom. Journal of International Business Education, 14, 265-286.

Arthur, N., \& Achenbach, K. (2002). Developing Multicultural Counseling Competencies through Experiential Learning. Counselor Education \& Supervision, 42(1), 2-14.

Baker, R.E., Simon, J.R., \& Bazeli, F.P. (1986). An Assessment of the Learning Style Preferences of Accounting Majors. Issues in Accounting Education, 1(1), 1-12.

Ballard, C., \& Johnson, M. (2005). Gender, Expectations, and Grades in Introductory Microseconds at a US University. Feminist Economics, 111(1), 95-122. 
Ben-Ari, A.T. (1998). An Experiential Attitude Change: Social Work Students and Homosexuality. Journal of Homosexuality, 36(2), 59-72.

Bethell, S., \& Morgan, K. (2011). Problem-Based and Experiential Learning: Engaging Students in an Undergraduate Physical Education Module. Journal of Hospitality, Leisure, Sport \& Tourism Education, 10(1), 128-134.

Borg, M.O., \& Stranahan, H. (2002). The Effect of Gender and Race on Student Performance in Principles of Economics: The Importance of Personality Type. Applied Economics, 34(5), 589598.

Breunig, M. (2005). Turning Experiential Education and Critical Pedagogy Theory into Praxis. Journal of Experiential Education, 28(2), 106-122.

Bruer, J.T. (1993). Schools for Thought: A Science of Learning in the Classroom. MIT Press, Cambridge, MA.

Caine, R.N., \& Caine, G. (1994). Making Connections: Teaching and the Human Brain. Menlo Park, CA: Addison-Wesley, 156.

Carpenter, V.L., Friar, S., \& Lip, M. (1993). Evidence on the Performance of Accounting Students: Race, Gender, and Expectations. Issues in Accounting Education, 8(1), 1-17.

Charkins, R.J., O’Toole, D.M., \& Wetzel, J.N. (1985). Linking Teacher and Student Learning Styles with Student Achievement and Attitudes. Journal of Economic Education, 16(2), 187-206.

Communicator. (1996). Not Just Bean Counters-Jelly Bean Counters. Two-Year College Section of the American Accounting Association.

Cornell, R.M., Johnson, C.B., \& Schwartz, W.C., Jr. (2013). Enhancing Student Experiential Learning with Structured Interviews. Journal of Education for Business, 88(3), 136-146.

Dabbour, K.S. (1997). Applying Active Learning Methods to the Design of Library Instruction for a Freshman Seminar. College of Research Libraries, 58(4), 299-308.

Davis, B.G. (1993). Tools for Teaching. San Francisco. Jossey-Bass.

DeNeve, K.M., \& Heppner, M.J. (1997). Role Play Simulations: The Assessment of an Active Learning Technique and Comparisons with Traditional Lectures. Innovative Higher Education, 21(3), 231246.

Dewar, B., \& Walker, E. (1999). Experiential Learning: Issues for Supervision. Journal of Advanced Nursing, 30(6), 1459-1467.

Dopuch, N., \& Pincus, M. (1998). Evidence on the Choice of Inventory Accounting Methods: LIFO versus FIFO. Journal of Accounting Research, 26(1), 28-59.

Doran, B.M., Bouillon, M.L., \& Smith, C.G. (1991). Determinants of Student Performance in Accounting Principles I and II. Issues in Accounting Education, 6(1), 74-84.

Duff, A. (2004). Understanding Academic Performance and Progression of First-Year Accounting and Business Economics Undergraduates: The Role of Approaches to Learning and Prior Academic Achievement. Accounting Education, 13(4), 409-430.

Dunn, K.A., Hooks, K.L., \& Kohlbeck, M.J. (2016). Preparing Future Accounting Faculty Members to Teach. Issues in Accounting Education, 31(2), 155-170.

Fedoryshyn, M.W., O’brien, M., Hintz, A., \& Bosner, K. (2010). Arithmetical Reasoning Skills as a Predictor of Success in Principles of Accounting. Academy of Educational Leadership Journal, 14(Special Issue), 93-107.

Gaidis, W., \& Andrews, J. (1990). An Experiential Approach for Integrating Ethical Analysis into Marketing Coursework. Journal of Marketing Education, 12(2), 3-9.

Gist, W.E., Goedde, H., \& Ward, B.H. (1996). The Influence of Mathematical Skills and Other Factors on Minority Student Performance in Principles of Accounting. Issues in Accounting Education, 11(1), 49-60.

Gray, M., \& Gibbons, J. (2002). Experience-Based Learning and Its Relevance to Social Work Practice. Australian Social Work, 55(4), 279-291. 
Hamer, L. (2000). The Additive Effects of Semi Structured Classroom Activities on Student Learning: An Application of Classroom-Based Experiential Learning Techniques. Journal of Marketing Education, 22(1), 25-34.

Keeton, M.T., \& Tape, P.J. (1978). Learning by Experience: What, Why, How. New Directions for Experiential Learning, the Boom in Experiential Learning, (1), 1-8. San Francisco, Jossey-Bass

Kendrick, J.R. (1996). Outcomes of Service Learning in an Introduction to Sociology Course. Michigan Journal of Community Service Learning, 3(1), 72-81.

Kern, B. (2002). Enhancing Accounting Students' Problem-Solving Skills: The Use of a Hands-On Conceptual Model in an Active Learning Environment. Accounting Education, 11(3), 235-256.

King, A. (1993). From Sage on the Stage to Guide on the Side. College Teaching, 4l(1), 72-81.

Koh, M.Y., \& Koh, H.C. (1999). The Determinants of Performance in an Accountancy Degree Programme. Accounting Education, 8(1), 13-29.

Kolb, A.Y., \& Kolb, D.A. (2005). The Kolb Learning Style Inventory - Version 3.1: Technical Specifications. Boston, MA: Hay Resources Direct.

Kolb, D. (1984). Experiential Learning: Experience as the Source of Learning and Development. New Jersey, Prentice Hall.

Kolb. D.A., \& Fry, R. (1975). Toward an Applied Theory of Experiential Learning. In C. Cooper (Ed.), Theories of Group Process. London: John Wiley.

Laux, J. (2007). Accounting issues: An Essay Series Part III-Inventory. Journal of College Teaching \& Learning, 4(8), 1-5.

Lave, J., \& Wegner, E. (1991). Situated Learning: Legitimate Peripheral Participation. New York, Cambridge University Press.

Lawson, T.J. (1995). Active Learning Exercise for Consumer Behavior Classes. Teaching of Psychology, 22(3), 200-202.

Lewis, L.H., \& Williams, C.J. (1994). Experiential Learning: Past and Present. New Directions for Adult and Continuing Education, 62, 5-16.

Light, R. (1990). The Harvard Assessment Seminars. Cambridge: Harvard University Graduate School of Education.

Lightweis, S. (2014). Bridging the Gap between Accounting Students and the Profession: A Case Study. Higher Education Studies, 4(5), 18-27.

Lumsden, K.G., \& Scott, A. (1987). The Economics Student Reexamined: Male-Female Differences in Comprehension. Journal of Economic Education, 18(4), 365-375.

Manorom, K., \& Pollock, Z. (2006). Role Play as a Teaching Method: A Practical Guide. Ubon Ratchathani University.

Mavruk, T. (2019). Do Men Outperform Women in Finance Classes? Journal of International Business Education, 14, 75-98.

Mccarthy, P., \& Anderson, L. (2000). Active Learning Techniques versus Traditional Teaching Styles: Two Experiments from History and Political Science. Innovative Higher Education, 24(4), 279 294.

Millenbah, K., \& Millspaugh. J. (2003). Using Experiential Learning in Wildlife Courses to Improve Retention, Problem Solving, and Decision-Making. Wildlife Society Bulletin, 31(1), 127-137.

Miller, J.E., \& Groccia, J.E. (1997). Are Four Heads Better Than One? A Comparison of Cooperative and Traditional Teaching Formats in an Introductory Biology Course. Innovative Higher Education, 21(4), 253-273.

Montgomery, K., Brown, S., \& Deery, C. (1997). Simulations: Using Experiential Learning to Add Relevancy and Meaning to Introductory Courses. Innovative Higher Education, 21(3), 217-229.

Nnodim, J.O. (1997). A Controlled Trial of Peer-Teaching in Practical Gross Anatomy. Clinical Anatomy, 117(92), 112-117.

O'Hara, B.S., \& Shaffer, T.R. (1995). Details and Students Perceptions of an Experiential Program for Personal Selling and Purchasing Class. Journal of Marketing Education, 17(1), 41-49. 
Perry, N.W., Matthew, T.H., Bradley, D.M., \& Julie, M.G. (1996). An Active-Learning Approach to

Teaching the Undergraduate Psychology and Law Course. Teaching of Psychology, 23(2), 76-81.

Ramsden, P. (1992). Learning to Teach in Higher Education. London, Routledge.

Rocha, C.J. (2000). Evaluating Experiential Teaching Methods in a Policy Practice Course: The Case for

Service Learning to Increase Political Participation. Journal of Social Work Education, 36, 53-63.

Schon, D. (1983). The Reflective Practitioner. New York, Basic Books.

Shakarian, D.C. (1995). Beyond Lecture: Active Learning Strategies That Work. Journal of Physical

Education, Recreation and Dance, 66(5), 21-24.

Sheorey, P., Naidu, A., Joshi, G., Sharma, D., \& Bhattacharya, S. (2020). Service Based Experiential Learning in Management Education: A Case Study from an Emerging Economy. Journal of International Business Education, 15, 00-00.

Siegel, P.H., Khursheed, O., \& Surendra, P.A. (1997). Video Simulation of an Audit: An Experiment in Experiential Learning Theory. Accounting Education, 6(3), 217-230.

Sternberg, R.J., \& Zhang, L.F. (2001). Perspectives on Thinking, Learning and Cognitive Styles. Mahwah, NJ: Lawrence Erlbaum.

Stice, J.E. (1987). Using Kolb's Learning Cycle to Improve Student Learning. Engineering Education, 77(5), 291-296.

Sunder, S. (1973). Relationship between Accounting Changes and Stock Prices: Problems of Measurement and Some Empirical Evidence. Journal of Accounting Research, 11, 1-45.

Tompkins, P.K. (1998). Role Playing/Simulation. The Internet TESL Journal, 4(8), 143-150.

Walters, G.A., \& Marks, S.E. (1981). Experiential Learning and Change: Theory, Design, and Practice. New York, John Wiley.

White, H. (1980). A heteroskedasticity-Consistent Covariance Matrix Estimator and a Direct Test for Heteroskedasticity. Econometrica, 48(4), 817-838.

\section{APPENDIX A1 VARIABLE DEFINITIONS}

\begin{tabular}{|c|c|}
\hline Grade & $=$ numerical value \\
\hline GENDER & $\begin{array}{l}=\text { code as } \\
0 \text { - female } \\
1-\text { male }\end{array}$ \\
\hline AGE & $=$ numerical value \\
\hline STANDING & $\begin{array}{l}=\text { code as } \\
\text { 1- freshman } \\
\text { 2- sophomore } \\
\text { 3- junior } \\
\text { 4- senior }\end{array}$ \\
\hline MATHEMATICS & $\begin{array}{l}\text { = code as } \\
\text { 1- one math course taken } \\
\text { 2- two math courses taken }\end{array}$ \\
\hline CONFIDENCE & $\begin{array}{l}\text { = code as } \\
\text { 1- not at all } \\
\text { 2- not much } \\
\text { 3- somewhat } \\
\text { 4- quite a bit } \\
\text { 5- a lot } \\
\text { Survey scale and results for "useful for learning material" questions; }\end{array}$ \\
\hline EXPERIENTIAL & $\begin{array}{l}=\text { code as } \\
0 \text { - traditional Methods group }\end{array}$ \\
\hline
\end{tabular}

70 Journal of Leadership Accountability and Ethics Vol. 18(2) 2021 


\begin{tabular}{|l|l|}
\hline & 1- experiential learning group \\
\hline MAJOR & - code as \\
& 1- not declare \\
& 2- accounting \\
& 3- finance \\
& 4- management \\
& 5- marketing \\
& 6- other \\
\hline
\end{tabular}

APPENDIX A2

NUMERICAL EXAMPLE

White Co. including transactions during the accounting period (Kern, 2002)

\begin{tabular}{|l|l|l|l|}
\hline Information & Number Of Units & Unit Cost & Total \\
\hline Beginning Inventory & 100 & $\$ 10$ & $\$ 1000$ \\
\hline Sale No. 1 & 25 & & \\
\hline Purchase No. 1 & 200 & $\$ 20$ & $\$ 4000$ \\
\hline Sale No. 2 & 75 & & \\
\hline Purchase No. 2 & 100 & $\$ 30$ & $\$ 3000$ \\
\hline
\end{tabular}

\begin{tabular}{|l|l|l|}
\hline & Cost of Goods Sold & Ending Inventory \\
\hline FIFO & & \\
\hline LIFO & & \\
\hline Weighted Average & & \\
\hline Gross Margin & & \\
\hline
\end{tabular}

\section{APPENDIX A3 \\ ASSESSMENT INSTRUMENT}

Pink Co. including transactions during the accounting period (Kern, 2002)

\begin{tabular}{|l|l|l|}
\hline Information & Number Of Units & Unit Cost \\
\hline Beginning Inventory & 200 & $\$ 20$ \\
\hline Purchase No. 1 & 300 & 23 \\
\hline Sale No. 1 & 250 & 50 \\
\hline Purchase No. 2 & 150 & 25 \\
\hline Sale No. 2 & 50 & 50 \\
\hline
\end{tabular}

1. a. How many units were sold during the time period?

b. How many units are in cost of goods available for sale?

2. What is cost of goods available for sale assuming a FIFO perpetual system?

3. What is cost of goods sold assuming a FIFO perpetual system?

4. What is cost of goods sold assuming a LIFO perpetual system?

5. What is ending inventory assuming a FIFO perpetual system?

6. What is ending inventory assuming a LIFO perpetual system?

7. What is cost of goods sold assuming a Weighted Average system?

8. What is ending inventory assuming a Weighted Average system?

9. If prices are rising, will LIFO or FIFO minimize taxes? 
10. a. Will LIFO or FIFO result in the most recent costs appearing on the balance sheet for a valuation of inventory?

b. Will LIFO or FIFO result in the most current prices being used to determine cost of goods sold?

11. Do you think that this lecture techniques are found to be useful to build confidence for learning material? (Students were asked to rate the extent to which they found the traditional lecture/experiential learning techniques to be useful to build confidence for learning material. The rating scale used is presented in the Appendix A1.)

72 Journal of Leadership Accountability and Ethics Vol. 18(2) 2021 